\title{
EFEKTIVITAS MANAJEMEN BIMBINGAN PRA NIKAH BP4 DALAM MEWUJUDKAN KELUARGA SAKINAH, MAWADDAH, WARAHMAH DI KUA KECAMATAN WANAREJA KABUPATEN CILACAP
}

\author{
Nono Carsono \\ KUA Kecamatan Wanareja Kabupaten Cilacap \\ email.nono.csf@gmail.com
}

\begin{abstract}
ABSTRAK
Kantor Urusan Agama (KUA) Kecamatan berperang penting dalam melaksanakan pembinaan dan pelayanan keluarga sakinah, sesuai dengan KMA Nomor 3 Tahun 1999 tentang pembinaan gerakan keluarga sakinah. Tujuan penelitian ini adalah untuk mengetahui efektivitas manajemen bimbingan pra nikah BP4 dalam mewujudkan keluarga sakinah, mawaddah, warahmah di KUA Kecamatan Wanareja Kabupaten Cilacap. Dalam menjawab tujuan tersebut, peneliti menggunakan pendekatan Manajemen. Penelitian ini tergolong penelitian kulitatif, Data dikumpulkan dengan menggunakan beberapa cara yang dianggap relevan dengan penelitian, diantaranya observasi, wawancara, dokumentasi, metode analisis data dan metode penentuan informan, jumlah informan dalam penelitian ini adalah Hasil penelitian menunjukkan Pelaksanan bimbingan pra nikah di Kantor Urusan Agama kecamatan Wanareja dianggap sudah efektif, namun demikian masih ditemukan pasangan calon pengantin yang masih sangat sulit memahami materi kursus pra nikah yang disampaikan oleh Konselor disebabkan kurangnya atau rendahnya pendidikan calon pengantin, dan masih perlu tindak lanjut peningkatan pelayanan pembinaan pasangan suami-isteri dalam pembentukan keluarga yang lebih mapan lagi dan tercermin dalam keluarga sakinah, mawaddah, warahmah.
\end{abstract}

Kata Kunci: BP4, Pernikahan, Penghulu, Keluarga

\section{PENDAHULUAN}

Perubahan lingkungan organisasi yang semakin kompleks dan kompetitif, menuntut setiap organisasi untuk bersikap lebih responsif agar memperthankan budaya organisasi yang baik. Proses menyelaraskan perubahan organisasi dengan perubahan individu ini tidaklah mudah. Pemimpin sebagai panutan dalam organisasi, sehingga perubahan harus dimulai dari tingkat yang paling atas yaitu pemimpin itu sendiri. Maka dari itu, organisasi memerlukan pemimpin reformis yang mampu menjadi motor penggerak yang mendorong perubahan organisasi.
Sampai saat ini, kepemimpinan masih menjadi topik yang menarik untuk dikaji dan diteliti, karena paling sering diamati namun merupakan fenomena yang sedikit dipahami. Fenomena kepemimpinan di Indonesia menjadi sebuah masalah menarik dan berpengaruh besar dalam kehidupan politik dan bernegara. Dalam dunia bisnis, kepemimpinan berpengaruh kuat terhadap jalannya organisasi dan kelangsungan hidup organisasi. Peran kepemimpinan sangat strategis dan penting dalam sebuah organisasi sebagai salah satu penentu keberhasilan dalam pencapaian misi, visi dan tujuan suatu organisasi. 
Maka dari itu, tantangan dalam mengembangkan strategi organisasi yang jelas terutama terletak pada organisasi di satu sisi dan tergantung pada kepemimpinan yang ada pada organisasi tersebut. Begitu pentingnya peran kepemimpinan dalam sebuah organisasi menjadi fokus yang menarik perhatian para peneliti bidang perilaku keorganisasian.

Pemerintah perlu mengetahui motivasi para bawahannya, karena hal tersebut mungkin dapat menjadi salah satu faktor yang menentukan jalan tidaknya pekerjaan dari visi dan misi yang dijabarkan dalam pencapaian kinerja bawahan dan tujuan pemerintah secara keseluruhan. Dalam Islam, bekerja dinilai sebagai kebaikan, sementara kemalasan dinilai sebagai keburukan.

Dalam rangka menunjang tugas dan fungsi pemerintah Kabupaten Cilacap terkhusus pada Kantor Urusan Agama Kecamatan Wanareja, sebagai aparat pemerintah daerah maka berbagai kegiatan yang perlu diperhatikan antara lain: meningkatkan kualitas sumber daya manusia yang beriman, bertaqwa dan berakhlak mulia dan mengefektifkan bimbingan pra nikah yang memiliki etos kerja produktif dan professional, memiliki kemampuan menerapkan ilmu pengetahuan dan teknologi yang berwawasan lingkungan, dan berkemampuan manajemen. Oleh karena itu, bimbingan bagi masyarakat yang akan melangsungkan pernikahan khususnya calon mempelai pria dan wanita sangatlah penting agar dapat mewujudkan keluarga sakinah, mawaddah, warahmah.

Melihat kedudukan dan fungsinya Kantor Urusan Agama (KUA) harus mampu menunjukan eksistensinya sebagai sebuah Instansi kepanjangan tangan dari Kementerian Agama dalam melaksanakan pelayanan publik di bidang urusan agama Islam. Hal ini perlu mendapatkan perhatian yang cukup serius. Sebab jika tidak, maka KUA akan senantiasa dikesankan oleh masyarakat luas hanya berfungsi sebagai lembaga yang mengurusi pelayanan pernikahan dan rujuk semata. Andaikata kondisi semacam ini tetap dipertahankan, maka KUA pada khususnya dan Kementerian Agama pada umumnya akan kurang mendapat perhatian dari masyarakat.

Kantor Urusan Agama (KUA)

Kecamatan berperang penting dalam melaksanakan pembinaan dan pelayanan keluarga sakinah, sesuai dengan KMA Nomor 3 Tahun 1999 tentang pembinaan gerakan keluarga sakinah poin empat berbunyi di kecamatan dibentuk Satuan Tugas (SATGAS) yang dipimpin oleh Kepala Kantor Urusan Agama Kecamatan, dalam pelaksanaannya bekerjasama dengan Kasi Pengembangan Masyarakat Desa pada Kantor Camat, Badan Penasehat Pembinaan Pelestarian Perkawinan (BP4), dan Pengawas Pendidikan Agama Islam. Dalam penerapan pelaksanaan pernikahan di KUA Kecamatan Wanareja itu senantiasa berjalan sesuai dengan aturan yang berlaku, baik sesuai dengan perundang-undangan maupun sesuai dengan tuntunan ajaran agama Islam.

Berdasarkan hasil pengamatan sementara, realitas budaya organisasi, kepemimpinan, kepuasan kerja dan kinerja pegawai Kantor Urusan Agama Kabupaten Cilacap masih rendah, dengan fenomena sebagai berikut:

1. BP4 tidak berjalan secara organisasi, karena jadi lembaga di luar KUA.

2. Anggaran tidak ada, yang ada sekarang dikelola bimas Islam di kemenag kabupaten, ketika mengadakan sifatnya menyesuaikan anggaran, untuk kumpul dalam waktu yg bersamaan sulit menentukan waktu karena jadwal hari nikah yang menentukan keluarga bukan KUA.

3. Yang bisa dilakukan KUA memberi penasehatan ketika hadir pemeriksaan pendafraran, dan ketika akan pelaksanaan aqad. 
4. Kegiatan yang sekarang diadakan program dari pusat BIMBINGAN PERKAWINAN (Binwin)

5. Untuk mencapai sasaran adalah bimbingan pra nikah, teknis secara nasional setiap KUA menyelenggarakan bimbingan pra nikah berkala 3 bulan sekali pesertanya siapa saja alamat nya mana saja boleh, sertifikat sebagai syarat utk menikah.

\section{KAJIAN PUSTAKA \\ 1. Pengertian Manajemen}

G.R. Terry $(2016 ; 16)$ menjelaskan bahwa manajemen merupakan suatu proses khas yang terdiri atas tindakan-tindakan perencanaan, pengorganisasian, mengggerakan, dan pengendalian untuk mennetukan serta mencapai tujuan melalui pemanfaatan sumber daya manusia dan sumber daya lainnya. Handoko (2019:8) mendefinisikan manajemen adalah proses perencanaan, pengorganisasian, pengarahan, dan pengawasan usahausaha para anggota organisasi dan penggunaan sumber daya - sumber daya organisasi lainnya agar mencapai tujuan organisasi yang telah ditetapkan. Sedangkan menurut Hasibuan (2013;1), manajemen adalah ilmu dan seni mengatur proses pemanfaatan sumber daya manusia dan sumber-sumber lainnya secara efektif dan efisien.

Dari beberapa definisi diatas dapat diartikan manajemen adalah proses perencanaan, pengorganisasian, pengendalian, dan pengawasan untuk mencapai tujuan yang telah ditetapkan secara efektif dan efisien.

\section{Bimbingan Pranikah}

Secara etimologis, kata bimbingan merupakan terjemahan dari bahasa inggris yaitu „guidance" yang berasal dari kata kerja "to guide" yang mempunyai arti menunjukkan, membimbing, menuntun maupun membantu" sesuai dengan istilahnya, secara umum bimbingan dapat diartikan sebagai suatu bantuan atau tuntutan (Suhertina, 2016).

Bimbingan pranikah atau kursus calon pengantin dilaksanakan atas dasar dikeluarkannya Peraturan Dirjen Bimas Islam No. DJ.II/491 tahun 2009, berbunyi" Kementrian Agama menyediakan sarana penyelenggaraan kursus calon pengantin".

Tujuan dari suscatin/ kursus Pranikah tersebut antara lain antara lain untuk mewujudkan keluarga yang harmonis dan sakinah yang dimaksud adalah keluarga yang didasarkan atas perkawinan yang sah, mampu memenuhi hajat spiritual dan materil secara serasi dan seimbang, diliputi suasana kasih sayang antara internal keluarga dan lingkungannya, mampu memahami, mengamalkan dan memperdalam nilai-nilai keimanan, ketaqwaan dan akhlakul karimah (Walgito, 2019).

Unsur-unsur pelaksanaan bimbingan pranikah sesuai dengan peraturan Direktur Jenderal Bimbingan Masyarakat Islam Kementrian Agama Nomor DJ.II/542 Tahun 2013. Dimaksudkan sebagai pedoman untuk para pejabat teknis dilingkungan Direktorat Jenderal Bimbingan Masyarakat Islam c.q Direktorat Urusan Agama Islam ditingkat pusat, Provinsi, Kabupaten atau Kota dan KUA Kecamatan serta Badan atau Lembaga yang melaksanakan kegiatan bimbingan Pra-nikah yang meliputi empat unsur sebagai berikut:

a. Jam Pelajaran (JPL)

Bimbingan Pranikah adalah pembekalan singkat (short cource) yang diberikan kepada remaja usia nikah atau calon pengantin dengan waktu tertentu yaitu selama 16 jam pelajaran (JPL) selama 3 (tiga) hari atau dibuat beberapa kali pertemuan dengan JPL yang sama. Waktu pelaksanaan dapat disesuaikan dengan kesempatan yang dimiliki peserta. 
b. Materi

Materi disampaikan dengan metode ceramah, dialog, Tanya jawab, simulasi dan penugasan yang pelaksanaanya dapat disesuaikan dengan kondisi dan kebutuhan di lapangan.

c. Narasumber

Narasumber atau penasehat yang dimaksud adalah orang yang dianggap cakap dan mampu untuk menyampaikan maksud dan tujuan dalam pelaksanaan bimbingan pranikah adalah orang yang mempunyai keahlian dibidang tertentu.

d. Metode Bimbingan

Dalam pelaksanaan bimbingan pranikah tentu menggunakan metode ceramah, dialog, diskusi, Tanya jawab, serta studi kasus sesuai dengan kondisi dilapangan

\section{Metode Penelitian}

Penelitian ini merupakan penelitian kualitatif yang dalam pengumpulan datanya menggunakan metode deskriptif, yaitu pengumpulan data dari responden. Penelitian kualitatif adalah penelitian yang secara holistik bermaksud untuk memahami fenomena tentang kejadian yang dialami subjek penelitian, baik itu perilakunya, persepsi, motivasi maupun tindakannya, dan secara dekskriptif dalam bentuk kata-kata dan bahasa, pada suatu konteks khusus yang alamiah dan dengan memanfaatkan berbagai metode alamiah.

Metode pendekatan yang digunakan dalam penelitian adalah pendekatan manajemen, yaitu secara langsung mendapat informasi dari informan. Peneliti akan menggunakan metode pendekatan Manajemen ini kepada pihak-pihak yang dianggap relevan dijadikan narasumber untuk memberikan keterangan terkait penelitian yang akan dilakukan. Pendekatan manajemen pada hakikatnya sangatlah baik karena didalamnya sudah mencakup unsur-unsur manajemen yang secara garis besar sudah mencakup semuanya. Ini menandakan bahwa setiap disiplin ilmu dan elemen kehidupan membutuhkan manajemen, terlebih lagi pada disiplin ilmu dakwah dalam penelitian ini, yang mengandung simbolsimbol islami didalamnya.

Penelitian yang menggunakan metode kualitatif, peran informan merupakan hal yang sangat penting dan perlu. Penentuan sampel atau informan dalam penelitian kualitatif berfungsi untuk mendapatkan informasi yang maksimum.

Alat pengumpulan data yang dilakukan dengan cara mengamati dan mencatat, menganalisa secara sistematis. Observasi ini penulis akan gunakan untuk mendapatkan data tentang Efektivitas manajemen dan bimbingan pra nikah BP4 dalam mewujudkan keluarga sakinah, mawaddah, warahmah. Data yang ingin diperoleh dari metode dokumentasi adalah data mengenai gambaran umum lokasi penelitian, dan historikalnya.

\section{Hasil Penelitian dan Pembahasan \\ 1. Manajemen Bimbingan Pranikah}

Manajemen bimbingan pra nikah yang dilaksanakan di Kantor Urusan Agama kecamatan Wanareja yakni, Calon pengantin yang sudah memenuhi syarat sebagaimana yang diatur dalam undangundang perkawinan maupu yang diatur dalam aturan agama, harus mengikuti kursus calon pengantin dengan membawa Permohonan untuk dikursus catin untuk mendapatkan materi bimbingan oleh petugas yang ditugaskan oleh pengurus BP4. Adapun tema materi yang disampaikan yakni:

a. Dasar dan tujuan perkawinan baik bedasarkan peraturan perundangundangan maupun berdasarkan ajaran agama Islam

b. Syarat, Rukun dan Larangan perkawinan

c. Hak dan kewajiban suami istri serta,

d. Upaya pembentukan keluarga sakinah yang meliputi:
1) Mewujudkan harmonisasi hubungan suami istri 
2) Membina hubungan antara anggota keluarga dan lingkungan,

3) Melaksanakan pembinaan kesejahteraan keluarga dan, Membina kehidupan beragama dalam keluarga.

\section{Penerapan Fungsi Manajemen dalam Pelaksanaan Pra Nikah}

a. Tahap Perencanaan

Hal pertama yang harus dilakukan oleh calon pengantin yaitu menuju ke pemerintah setempat atau RT/RW untuk mengurus surat pengantar nikah kemudian dibawa ke Kekepala desaan. Selanjutnya calon pengantin ke Kantor Kepala desa untuk mengurus surat pengantar nikah (N1-N4) untuk dibawa ke KUA Kecamatan. Kemudian apakah pernikahan itu dilakukan di luar KUA setempat, maka calon pengantin menuju ke KUA setempat untuk mengurus surat pengantar rekomendasi nikah untuk dibawa ke KUA Kecamatan tempat akad nikah. Namun apabila calon pengantin menikah di KUA setempat maka masih perlu ada pemeriksaan, apakah waktu pernikahan kurang dari 10 hari atau tidak? Kalau tidak, maka calon pengantin ke KUA Kecamatan melakukan pendaftaran nikah di KUA tempat dilaksanakannya akad nikah. Selanjutnya jika akad nikah dilakukan di luar Kantor KUA atau tidak, kalau tidak maka calon pengantin ke KUA Kecamatan melaksanakan pernikahan dengan biaya gratis, kemudian di KUA Kecamatan diadakan pemeriksaan data nikah calon pengantin dan wali nikah di KUA tempat akad nikah, kemudian diadakan pelaksanaan akad nikah dan penyerahan buku nikah. Sedangkan apabila waktu pernikahan kurang dari 10 hari maka calon pengantin mengajukan permohonan dispensasi nikah di kantor Kecamatan akad nikah, kemudian calon pengantin mendaftarkan pernikahannya di KUA setempat. Dan apabila pernikahan dilaksanakan diluar Kantor KUA maka calon pengantin menuju ke Bank persepsi yang ada di wilayah KUA tempat menikah untuk membayar biaya nikah sebanyak Rp. 600.000,- kemudian calon pengantin menyerahkan slip setoran biaya nikah ke KUA tempat akad nikah. Selanjutnya diadakan pemeriksaan data nikah calon pengantin dan wali nikah di KUA kemudian di lokasi akad nikah akan dilaksanakan akad nikah sekaligus penyerahan buku nikah.

b. Tahap Pengorganisasian

Pelaksanaan akad nikah dilaksanakan oleh Kepala KUA, BP4, serta Pembantu P3N, itu dimulai dari persiapan yang pertama adalah kesiapan calon pengantin, apakah dia betul mau nikah atau tidak? Kalau betul-betul siap maka calon pengantin memulai mempersiapkan suratsurat yang diperlukan di pemerintah setempat, mulai ditingkat RW/RT, kepala desa, Kecamatan, atau langsung ke KUA setempat dimana akad nikah akan dilaksanakan.

c. Tahap Pelaksanaan

Setelah semua berkas calon pengantin sudah diadakan pemeriksaan dan sudah memenuhi syarat untuk dinikahkan, maka dilaksanakanlah akad nikah. Dimana akad nikah itu akan dilaksanakan, apakah di rumah atau di Kantor KUA Kecamatan setempat. Setelah akad nikah selesai maka dilanjutkan dengan penyerahan buku nikah. 
d. Tahap Kontrol/Evaluasi

Setelah peristiwa pernikahan dianggap telah selesai maka pengurus BP4 dalam hal ini sebagai lining sektor adalah kepala Kantor KUA itu senantiasa melakukan pembinaan kepada pasangan suami-isteri, baik melalui pengajian rutin, majelis taklim, maupun melalui konsultasi perorangan ataupun kelompok tetap melakukan pendampingan agar pasangan suami-isteri tetap dapat melanjutkan fungsi dan tugasnya masing-masing (terkait hak dan kewajiban) agar tercipta rumah tangga idaman yaitu keluarga sakinah, mawaddah, warahmah.

\section{Efektivitas Pelaksanaan bimbingan}

Pelaksanaan bimbingan pra nikah di KUA Kecamatan Wanareja, dapat dipahami bahwa dari banyaknya pernikahan pada tahun 2020 terdapat peristiwa perceraian atau pasangan yang bermasalah yang berujung pada perceraian, oleh karena itu dari analisa penulis bahwa pelaksanan bimbingan pra nikah di Kantor Urusan Agama kecamatan Wanareja sudah dianggap efektif, namun demikian masih ditemukan pasangan calon pengantin yang masih sangat sulit memahami materi kursus pra nikah yang disampaikan oleh Konselor disebabkan kurangnya atau rendahnya pendidikan calon pengantin, dan juga masih perlu tindak lanjut peningkatan pelayanan pembinaan pasangan suami-isteri dalam pembentukan keluarga yang lebih mapan lagi dan tercermin dalam keluarga sakinah, mawaddah, warahmah.

a. Pendidikan atau kursus pra nikah

Peranan BP4 disini ialah memberikan pengetahuan sejak dini kepada setiap pasangan calon pengantin dalam bentuk pelatihan atau kursus. Kursus tersebut sebagai bekal awal setiap pasangan dalam mengarungi bahtera rumah tangga karena dalam kursus dibekali pengetahuan dasar dalam berumah tangga. Adapun materi-materi kursus pra nikah atau yang dikenal dengan kursus calon pengantin yakni sebagai berikut:

1) Dasar dan tujuan perkawinan dalam Islam

2) Syarat, rukun dan larangan perkawinan.

3) Hak dan kewajiban suami istri

4) Upaya pembentukan keluarga sakinah yang meliputi:

(a) Mewujudkan harmonisasi hubungan suami isteri.

(b) Membina hubungan antara anggota keluarga dan lingkungan.

(c) Melaksanakan pembinaan kesejahteraan keluarga dan

(d) Membina kehidupan beragama dalam keluarga.

Hal ini sangat penting karena suami dan isteri merupakan faktor utama dalam pembentukan sebuah keluarga bahagia. Damainya sebuah institusi perkawinan itu bergantung kepada hubungan dan peranan suami isteri untuk membentuk keluarga harmonis sebagaimana yang diharapkan. Dengan demikian pasangan suami isteri yang telah memahami tanggung jawab masing-masing, namun demikian yang teramat penting adalah adanya kesadaran untuk menjalankan tanggung jawab sebagai suami isteri yang lazim disebut tanggungjawab bersama. Suami merupakan kepala keluarga yang memainkan peranan paling penting untuk membentuk sebuah keluarga bahagia. Suami yang bahagia ialah suami yang sanggup 
berkorban dan berusaha untuk kepentingan keluarga dan rumah tangga yaitu memberi makan-makanan yang baik untuk anak-anak dan isteri, menjaga hak isteri, memberi pakaian yang bersesuaian dengan pakaian Islam, mendidik anak-anak dan isteri, dengan didikan Islam yang benar serta memberi tempat perlindungan. Isteri sholehah ialah isteri yang tahu menjaga hak suami, harta suami, anak-anak, menjaga diri dan juga suami serta membantu menjalankan urusan keluarga dengan sifat ikhlas, jujur, bertimbang rasa, amanah, dan bertanggung jawab. Tanggung jawab isteri terhadap ahli keluarganya amatlah besar dan ia hendaklah taat terhadap segala perintah suaminya selagi tidak bertentangan dengan larangan Allah.

b. Penyuluhan

Peranan BP4 tidak hanya sebatas pada saat pra nikah, namun pembinaan dan penyuluhan harus terus dikasanakan dengan melaksanakan kunjungan rutin ke masyarakt. Hal ini dapat dilakukan karena setiap BP4 memiliki perangkat berupa petugas penyuluh fungsional yang bertugas di setiap desa. Apabila hal ini dimaksimalkan maka keluarga sakinah dapat terwujud disetiap rumah tangga. Adanya kesadaran dan keinginan masyarakat untuk mengikuti setiap penyuluhan yang dilaksanakan oleh BP4, maka akan menambah pengetahuan dan terbangunya kesadaran suami-isteri tentang keluarga bahagia. Membina sebuah keluarga bahagia dengan asas yang kukuh terutamanya dengan pengetahuan keagamaan dapat menjadikan individu berfikir, dan bertindak sesuai dengan fitrah insaniah, yang diberikan oleh Allah swt. keluarga Islami harus selalu meningkatkan kualitas pemikiran Islam yang sebenarnya senantiasa sesuai dengan perubahan zaman.

c. Pembinaan kepada keluarga pra sakinah, sakinah 1 dan sakinah 2

Dalam kehidupan masyarakat tidak dapat dipungkiri adanya perbedaan status atau kategori antara satu keluarga dengan keluarga lainnya. hal ini terkait dengan faktor ekonomi, pendidikan dan pengetahuan agama serta pengalaman. Pengurusan ekonomi dalam rumah tangga seharusnya tidak dipandang remeh oleh setiap pasangan. Kedudukan ekonomi yang tidak stabil menyebabkan masalah yang akan timbul dalam rumah tangga. Masalah akan terjadi jika suami tidak dapat memberikan nafkah yang secukupnya, atau isteri terlalu mementingkannya aspek material di luar kemapuan suami atau keluarga. Sebaiknya, setiap keluarga harus mengukur kemampuan masing-masing agar jangan sampai aspek ekonomi rumah tangga sebagai sebab bergolaknya keluarga dan penghalang untuk membentuk sebuah keluarga bahagia. Selain itu pendidikan juga menjadi sangat penting dalam mengukur kemampuan seseorang dalam memahami dan menjalankan pengetahuan yang mereka terima, khususnya pengetahuan agama. Keluarga yang memiliki pendidikan pengetahuan agama yang baik maka mampu melaksanakan tuntunan agama dengan baik pula sehingga tujuan terciptanya keluarga bahagia atau sakinah dapat terwujud. Dalam 
masyarakat terdapat perbedaan dalam bidang ekonomi, pendidikan dan pengalaman agama, maka BP4 berperan untuk melakukan pembinaan kepada masyarakat tersebut dengan pendekatan komunikasi dua arah, dialog dan terjun langsung ke rumah-rumah. BP4 bukan hanya melakukan pelayanan administrasi di kantor melainkan aparaturnya harus terjun langsung ke lapangan dan melakukan bimbingan ke setiap individu, dan dapat memahami karakter dari setiap masyarakat, dapat lebih mengetahui persoalanpersoalan yang dihadapi setiap rumah tangga. Oleh karena itu, upaya yang dilakukan BP4 dapat mengefektifkan program yang sedang dijalankan dan manfaatnya dapat meminimalisir angka perceraian khususnya di Kecamatan Wanareja.

\section{Kesimpulan}

Strategi manajemen bimbingan pra nikah yang dilaksanakan di Kantor Urusan Agama kecamatan Wanareja yakni, calon pengantin yang sudah memenuhi syarat sebagaimana yang diatur dalam undang-undang perkawinan maupun yang diatur dalam aturan agama, harus mengikuti kursus calon pengantin dengan membawa permohonan untuk mengikuti catin untuk mendapatkan materi bimbingan oleh petugas yang ditugaskan oleh pengurus $\mathrm{BP} 4$.

Pelaksanan bimbingan pra nikah di Kantor Urusan Agama kecamatan Wanareja dianggap sudah efektif, namun demikian masih ditemukan pasangan calon pengantin yang masih sangat sulit memahami materi kursus pra nikah yang disampaikan oleh Konselor disebabkan kurangnya atau rendahnya pendidikan calon pengantin, dan masih perlu tindak lanjut peningkatan pelayanan pembinaan pasangan suami-isteri dalam pembentukan keluarga yang lebih mapan lagi dan tercermin dalam keluarga sakinah, mawaddah, warahmah.

\section{Daftar Pustaka}

Abdul Rahman Ghozali, Fiqh Munakahat, Jakarta, Kencana, 2008. Bungin,

Burhan, Penelitian Kualitatif, Jakarta: Kencana, 2009.

BKKBN, Membangun Keluarga Sehat dan Sakinah, Jakarta, TP, 2008

Bisri, Moh Adib. Terjemah Al-Faraidul Bahiyyah Risalah Qawaidul Fiqh. Rembang: Menara Kudus, 1977

Badan Litbang dan Diklat Lajnah Pentashihan Mushaf Al-Qur'an, Membangun Keluarga Harmonis, Jakarta: Departemen Agama RI, 2008

Departemen Agama RI, Al-Qur'an dan Terjemahannya, Jakarta, PT Intermasa, 1993.

Direktorat Jenderal Pembinaan Kelembagaan Agama Islam, Ilmu Fiqh, Jakarta, 1984.

Djazuli, Fiqh Jinayah, Cet III, Jakarta: PT Raja Grafindo Persada, 2002

Direktorat Pembinaan Badan Peradilan Agama, , Kompilasi Hukum Islam di Indonesia, Jakarta, PT Raja Grafindo Persada, 1991/1992

Direktorat Jenderal Bimbingan Masyarakat Islam, Membina Keluarga Sakinah, Jakarta: Departemen Agama RI, 2008

Direktorat Jenderal Bimbingan Masyarakat Islam dan Penyelenggaraan Haji, Pedoman Pembantu Pegawai Pencacatan Nikah, Jakarta: Proyek Peningkatan Tenaga Keagamaan, 2004 
Eldin Achyar, Dakwah Stratejik, Jakarta: Pustaka Tarbiyatuna, 2003.

Gibson, Organisasi, Tangerang: Binarupa Aksara, 2010.

Humaedillah, Memed. Akad Nikah Wanita Hamil dan Anaknya, Cet.1. Jakarta: Gema Insani Press, 2002.

H. Hadari Nawawi, Manajemen Stratejik, (Organisasi Non Profit Bidang Pemerintahan), Yogyakarta: Gadjah Mada University Press, 2005.

Handoko, Tani, Strategi Organisasi, Amara Books: Yogyakarta, 2004.

Kamus Besar Bahasa Indonesia Kuncoro, Mudrajad, Strategi Bagaimana Meraih Keunggulan Kompetitif, Jakarta: Erlangga, 2006.

Malayu S.P. Hasibuan, Manajemen (Dasar, Pengertian dan Masalah), Jakarta, PT Bumi Aksara, 2007.

Moleong, Lexy J.Metode Penelitian Kualitatif, Bandung: PT. Remaja Rosdakarya, 2008.

Muhyidin Asep, Dakwah dalam Perspektif al-Qur'an: Studi Kritis atas Visi, Misi dan Wawasan, Bandung: Pustaka Setia, 2002.

Poernomo, Husaini Usman, Metodologi Penelitian Sosial, Jakarta: Bumi Aksara, 1996.

Prasetyo, Bambang. Lina Miftahul Jannah, Metode Penelitian Kuantitatif; Teori dan Aplikasi, Jakarta: PT. Raja Grafindo Persada, 2007.

Ramulyo, Mohd Idris. Hukum Perkawinan Islam. Jakarta: Bumi Aksara, 1996.
Setiawan Dimas, Kamus Praktis Modern Bahasa Indonesia, Jakarta: Bintang Indonesia, 2005.

Siagian Sondang. P, Manajemen Sumber Daya Manusia, Jakarta: Penerbit Bumi Aksara, 2006.

Sabiq Sayyid, Fiqih Sunnah, Jilid II, Beirut: Darul-Fikr, 1983.

Sudarwan Danim, Motivasi Kepemimpinan \& Efektivitas Kelompok, Jakarta: PT Rineka Cipta, 2004.

Sugiyono. Memahami Penelitian Kualitatif, Bandung: Alfabeta, 2008.

Syarifuddin Amir, Figh (garis-garis besar), Jakarta: Kencana, 2003.

Sujana, Nana, Tuntutan Penyusunan Karya Ilmiah, Bandung: Sinar Baru, 1988.

Sukma dinata, Nana Syaodih Pengembangan Kurikulum Teori dan Praktek, Bandung: Remaja Rosdakarya, 2009.

Sulaiman bin al-Asy'asy bin Ishaq, Abu Dawud. Sunan Abi Dawud, Juz 1. Bairut: Daral-Fi, 1983.

Syukir Asmuni, Dasar-dasar Strategi Dakwah Islam, Surabaya: Al Ikhlas, 1983.

Tripomo, T \& Udan, Manajemen Strategi, Bandung: Rekayasa Sains, 2005.

Wisnu CIR, Dicky, Teori Organisasi Struktur dan Desain, Malang: UMM Press, 2005.

Winardi, Teori Organisasi dan Pengorganisasian, Jakarta: PT Raja Grapindo Persada, 2003. 